\title{
Lipopolysaccharide (LPS) introduction during growth and development period of rat's tooth toward the occurrence of enamel hypoplasia
}

\author{
Didin Erma Indahyani*, Al-Supartinah Santoso ${ }^{* *}$, Totok Utoro ${ }^{* * *}$, and Marsetyawan HNE Soesatyo ${ }^{* * * * *}$ \\ * Department of Oral Biology, Faculty of Dentistry Jember University, Jember-Indonesia \\ ** Department of Pediatric Dentistry, Faculty of Dentistry Gadjah Mada University, \\ *** Department of Anatomy and Pathology, Faculty of Medicine Gadjah Mada University, Yogyakarta-Indonesia \\ **** Department of Histology, Faculty of Medicine Gadjah Mada University, Yogyakarta-Indonesia
}

\begin{abstract}
The aim of this study is to know the effect of lipopoly saccharide (LPS) induction during growth and development period specifically the occurrence of hypoplasia on tooth enamel. 5 day old male wistar rats divided into two groups. Group 1 (control) under went no treatment. Group 2 (treatment) under went LPS induction every 24 hour for 8 days on buccal fold right maxillary first molar. After 21 days old the rats were sacrificed and the tooth was resected. Hypoplasia Hypo calcification Index (HHI) was used to determine the degree of hypoplasia by clinical examination. Radiograph of maxilla was also taken to analyze the apacities of enamel by using COREL DRAW version 11. The result showed that group under went LPS induction hypoplasia occurred on its molar tooth and more radiolucent than control groups. The conclusion is LPS induction during growth and development period of rats tooth causing enamel hypoplasia.
\end{abstract}

Key words: lipopolysaccharide, growth and development tooth, hypoplasia, rat

Correspondence: Didin Erma Indahyani, c/o: Bagian Biologi Oral, Fakultas Kedokteran Gigi Universitas Jember. Jln. Kalimantan 37 Jember 68121, Indonesia.

\section{INTRODUCTION}

Growth and development of tooth consist of several stages; complex process and involve coordination as well as interaction between neural crest and epitel. ${ }^{1}$ The stage and process consist of initiation (bud stage), proliferation (cap stage) histodifferentiation and morfodifferentiation (bell stage), apposition as well as calcification (mineralization). The change occurring during the period of growth and development would contribute tooth abnormality. The change might be resulted from various kind of local and systemic factors. $^{2}$

One of local factors inducing tooth abnormality is bacterial infection during the period of tooth growth and development. Periapical lesion and alveolar bone impairment affected by either bacteria or product of other bacteries, one of them is lipopolysaccharide (LPS). LPS is the main structure of cell wall of gram negative bacteria to maintain the integrity of bacterial structure and to protect the bacteria from host immunity. In addition, LPS is endotoxin contributing the occurrence of cytokine proinflammatory secretion from several types of cell. ${ }^{3}$ It could be suggested that LPS has an important role as the cause of periapical lesion. ${ }^{4}$ This condition would induce local factor cytokine proinflammatory such as: interleukin -1 (IL-1), IL-1, IL-6, tumor necrosis factor- (TNF-) and eikosanoid i.e. prostaglandin $\left(\mathrm{PGE}_{2}\right){ }^{5}$ Prostaglandine and cytokine proinflamatory might result distruction of periodontal tissue by stimulating the formation and the increase of osteoclast activities. ${ }^{6}$
Enamel hypolasia is one of abnormalities of tooth enamel which frequently found in children's teeth caused by the disturbance during the period of tooth growth and development. In general, clinical feature of enamel hypoplasia is shown by enamel agenesis which looks like a small well, horizontally arranged found on buccal region. If severe hypoplasia occurs, most parts of tooth enamel will disappear. ${ }^{7}$ Hypoplasia is called as quantitative abnormality, usually followed by hypocalcification which is called qualitative abnormality. ${ }^{8}$ Hypocalcification (demarcated opacities) resulted from imperfect mineralization on enamel and manifest in the form of white spot. ${ }^{7} \mathrm{Li}$ et $a{ }^{9}{ }^{9}$ reported that enamel hypoplasia of children's permanent teeth in rural area in China suspected caused by continuous caries on deciduous teeth which initially happened at the age of 3-5 years. Study condacted by Lo et al., ${ }^{10}$ Nicolau et al., ${ }^{11}$ and Broad Bent et al. ${ }^{12}$ suggested that demarcated opacities and hypoplasia which happened in permanent tooth due to severe caries on the previous deciduous teeth even though the mechanism was still unknown. The purpose of this study is to know the effect of LPS induction enamel hypoplasia. The outcome of the study is expected to be able to contribute scientific in formation on the mechanism of hypoplasia, so that local infection which could disturb the growth and development could be avoided. In addition, it is also expected as the basic guidance of further study in the future. 


\section{MATERIAL AND METHOD}

This study was performed on 10 male wistar rats of 5 days old, the rats were classified into 2 groups (5 rats each): groups 1: was controlled group which didn't undergo any treatment, groups 2: the rats were inducted using Escherichia coli LPS (sigma) with the dosage: $5 \mathrm{gr} / 0,005 \mathrm{ml}$ saline on buccal fold of right maxillary first molar. LPS induction was done by intra muscular injection once in 24 hours for 8 days. ${ }^{13}$ On the $21^{\text {st }}$ day the rats were decapitated. The maxilla was observed to find whether hypoplasia occurred or not enamel of right molar. The degree of hypoplasia was assessed by hypoplasia hypocalcification index (HHI) ${ }^{14}$ occurrence or hypocalcification, as follows 0 = no hypoplasia occurrence or hypo calcification, 1 = hypocalcification on half of incisal or occlusal crown, 2 = hypocalcification on half of cervical crown, 3 =hypoplasia on half incisal or occlusal crown, $4=$ hypoplasia on half of cervical crown, $5=$ hypocalcification less than half incisal occlusal crown, $6=$ hypocalcification more than half of incisal occlusal crown or affected more than one crown, 7 = hypoplasia less than half of incisal occlusal crown, $8=$ hypoplasia more than half insisal occlusal or affected more than one occlusal, and $9=$ hypocalcification/hypoplasia excluded the above criteria (disfusive hypoplasia, limited one occlusal expected incisal).

The result of radiopaque was put on $\mathrm{x}$-ray viewer, then, recorded by digital camera and the result was transferred into computer. Radiopaque and radiolucent feature of tooth enamel was observed using COREL DRAW version 11 (Corel, Ottawa Canada) assessing the size of red blue green (RGB) to see the difference of radiopaque of every radiopaque. ${ }^{15}$ The combination of RGB would produce white color, so, it is called additive color. The computer monitor would produce color shining ray through RGB. The mean of the total component of RGB would come maximal score $=255$, and it would show pure white while the mean of total RGB would come: 0, it would show pure black. Statistic analysis would be done using T-test in order to know whether there is or there is no statistical difference between the two groups either based on HHI radiopaque of radiopaque.

\section{RESULT}

There was no evidence of hypoplasia (Figure 1A) on the rats of groups 1 with HHI index $=0$ (either hypoplasia or hypocalcification undetected), meanwhile on the rats of group 2 hypoplasia was found in upper right molar (Figure 1-B). On radiopaque examinations showed that, group 1 had mean RGB higher than group 2, therefore, it could be suggested that the enamel showed more radiopaque companing to group 2 (Figure 2). The result of HHI examination and radiopaque feature of radiopaque could be seen on Table 1. Statistical analysis using T-test showed significant difference $(\mathrm{p}<0,005)$ between group 1 and 2 on HHI, radiopaque feature of radiopaque showed insignificant difference ( $\mathrm{p}>0,005)$ between group 1 and 2 (Table 2).
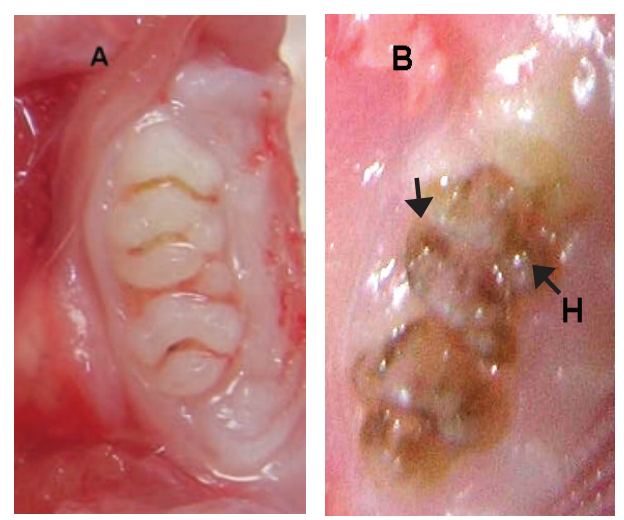

Figure 1. Rats molar enamel with and without enamel hypoplasia.

Note: A) Rat's molar in control group (without any treatment and enamel hypoplasia, B) Rat's molar in treated group, hypoplasia was found (LPS induction was done)
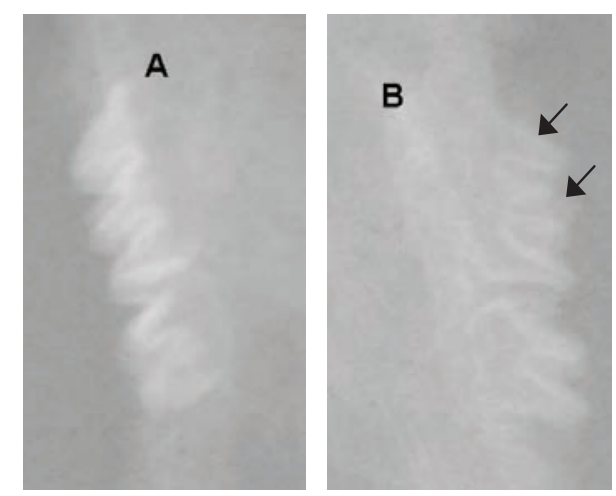

Figure 2. Radiopaque of rat's molar with and without enamel hypoplasia.

Note: A) Control group without treatment, B) Treated group with LPS induction. On figure $B$ is more radiolucent compared to figure $\mathrm{A} \rightarrow$ radiolucent enamel tooth

Table 1. The result of hypoplasia observation using hypoplasia hypocalcification index (HHI) and radiopaque observation using COREL DRAW version 11

\begin{tabular}{rccc}
\hline N & Groups & HHI & radiophaque \\
\hline 1 & I & 0 & 196,6 \\
2 & I & 0 & 198,4 \\
3 & I & 0 & 195,73 \\
4 & I & 0 & 196,2 \\
5 & I & 0 & 198,2 \\
6 & II & 8 & 180,5 \\
7 & II & 8 & 88,4 \\
8 & II & 8 & 170,87 \\
9 & II & 1 & 179,6 \\
10 & II & 3 & 102,1 \\
\hline
\end{tabular}

Note: $\mathrm{N}=$ sample; $\mathrm{HHI}=$ hypoplasia hypocalcification index 
Table 2. The result of T-test on the presentence of hypoplasia and radiopaque score of rats tooth enamel

\begin{tabular}{|c|c|c|c|c|c|c|c|}
\hline & \multicolumn{7}{|c|}{ t-test for Equality of Means } \\
\hline & \multirow[t]{2}{*}{$\mathrm{t}$} & \multirow[t]{2}{*}{ df } & \multirow[t]{2}{*}{ Sig. (2-tailed) } & \multirow{2}{*}{$\begin{array}{c}\text { Mean } \\
\text { Difference }\end{array}$} & \multirow[t]{2}{*}{$\begin{array}{l}\text { Std. Error } \\
\text { Difference }\end{array}$} & \multicolumn{2}{|c|}{$\begin{array}{l}95 \% \text { Confidence Interval of } \\
\text { the Difference }\end{array}$} \\
\hline & & & & & & Lower & Upper \\
\hline HHI & -3.725 & 4.000 & .020 & -5.60000 & 1.50333 & -9.77391 & -1.42609 \\
\hline radiopak & 2.608 & 4.006 & .059 & 52.73200 & 20.21627 & -3.36594 & 108.82994 \\
\hline
\end{tabular}

Note: $\mathrm{t}=\mathrm{t}$ count; $\mathrm{df}=$ degree of freedom; $\mathrm{sig}=$ significant HHI = hypoplasia hypocalcification index

\section{DISCUSSION}

The outcome of this study identified that LPS induction during the period of tooth growth and development resulting the presence of enamel hypoplasia. LPS consist of 3 parts: O-polysaccharide chain, core of polysaccharide and lipid-A. Lipid-A is a part of endotoxic LPS due to receptor CD14 bind / toll-like receptor-4 (TLR4). ${ }^{3}$ CD14 is receptor of cell surface on macrophage and monocyte. ${ }^{16,17}$ Macrophage and monocyte cell which make bacterial binding due to the presence of CD14 would secrete cytokine and lipid inflammation mediator. ${ }^{18}$ The study done by Yoshimura et al. ${ }^{19}$ suggested that LPS A. actinomycetemcomitans and E. coli are capable to induct PMN secreting IL-1 $\beta$, IL-8, TNF- $\alpha$ and interleukine receptor antagonist (IL-1ra) in large number, while PMN which inducted to LPS P. gingivalis, IL- $1 \beta$ is not detected. Monocyte which inducted by LPS P. gingivalis and $E$. coli would secret higher IL- $1 \beta$ than PMN. IL- $1 \beta$, IL- 8 and TNF- $\alpha$ stimulate the elevation of osteoclast amount and activities. Oseteoclast is kind of cell which functions in degradation of bone matrix. ${ }^{6}$ Induction LPS E. coli contributes the elevation of osteoclast number and activities and alveolaris bone resorption. ${ }^{13}$

Either chronic or acute local infection in periodontal tissue which are presented during the period of tooth growth might contribute the failure of dental germ to perform the stage growth i.e. initiation (bud stage) proliferation (cup stage), histodifferentiation and morfodifferentiation (bell stage), aposition as well as calcification resulting the presence of abnormality of the form, number, quality and the quantity of eruptive teeth. ${ }^{20}$ In enamel hypoplasia, failure is usually presented during the process of amelogenesis. ${ }^{2}$ According to Mc Donald \& Avery ${ }^{2}$ and Wikipedia: ${ }^{20}$ amelogenesis (enamel formation) is apart of the whole process of tooth growth. Amelogenesis occurs after perfect dentin formation done by ameloblast. Amelogenesis consist of two stages i.e. secretory stage (aposition) involving organic matrix formation and it is called enamel matrix, this stage functions during the process of enamel mineralization. The second stage is maturation i.e. enamel matrix has perfect calcification. ${ }^{2,20}$ Infection which is presented during the period of enamel matrix formation would contribute the occurrence of hypolasia and if happens during the period of calcification would contribute enamel hypocalcification. ${ }^{2}$

The stage of matrix aposition and deposition done by formative cell would be the most sensitive stage during the period of growth. ${ }^{21}$ LPS Induction resulting stimulation of osteoclast cell which could perform tissue resorption. Enamel prisms which has been deposited during aposition and deposition stage would be destroid. ${ }^{22}$ This case is due to stimulated osteoclast by LPS activity resulting the presence of resorption. In addition, ameloblast cell is the most sensitive cell environmental change. ${ }^{23}$ Physiologic change would affect ameloblast and contribute enamel structural change. In general the change could not be seen clinically but it would appear through the microscope. Disturbance or infection might result the disturbance of enamel matrix secretion by ameloblast or death of ameloblast. The presented abnormality usually would appear clinically. ${ }^{1}$

Basically, the growth and the development of rats and human molar indicate the same stage during embrional to eruption stage. ${ }^{24}$ Molar amelogenesis on rats has initiated since the age of 20-21 days intrauterine and perfectly formed at the age of 11 days post uterine. ${ }^{21}$ LPS induction done on 5 day-old rats resulting the disturbance of amelogenesis or going process. LPS contributes the presence of elevation IL- $1 \alpha$, IL- $1 \beta$, IL-6, tumor necrosis factor - (TNF- $\alpha$ ) and $\mathrm{PGE}_{2}$, consequently, increasing the number and the activity of osteoclast. This case would cause obstruction of alveolaris bone and the body would fail to stimulate the formation of fibrous wall which might localize the infection, as a result infection would disseminate on dental germ about $20-30 \%{ }^{25}$ The number and the activity of osteoclast and adontoclast would continually degrade either base matrix or enamel matrix which is newly formed dental germ and disturb ameloblast cell. On 5 day-old rats ameloblast cell is forming enamel matrix and deposition process of organic and inorganic material is occurring. LPS induction would cause the death of ameloblast cell therefore enamel matrix with would fail to be formed. In normal condition ameloblast cell secretes enamel matrix with certain immunity. ${ }^{1}$ Due to failure of enamel matrix formation, so there is some enamel which failed to be formed until the period of tooth eruption. As a result enamel becomes thin and either some holes would appear on the surface. 
After the thickness of enamel matrix is considered adequate by ameloblast cell, the function of ameloblast cell would change and have important role in the process of enamel maturation. During the occurrence of maturation process, the change of enamel organic component is presented either qualitatively or quantitatively. Other changes also happen in enamel organic component i.e. calcium and phosphate influx presented in short time. This condition can cause the presence of crystal growth located in loophole which formed due to disappearance of organic material and water. Striated border and alkaline phosphates in ameloblast have importance role on organic ion transport through cell membrane enamel maturation. ${ }^{1}$ The decrease and the presence of change on ameloblast cell due to LPS induction deposition process of either organic and inorganic material would be disturbed, so, the process of enamel mineralization is not perfect. Thin enamels due to mineralization disturbance which make the teeth look brownish yellow.

Brownish yellow color due to dentin appearance look transparent and several part of dentin opened. Dentin was looked yellower because the organic content is lower comparing to enamel. The radiophaque shows that rats with hypoplasia, the enamel is more radiolucent compared with control group (Figure 2). Solid material would adsorb X-ray stronger which causes the radiophaque clear (white) which is called radiophaque, while material with low density, the adsorption would be also weak, which gives dark region or it is called radiolucent. ${ }^{26,27}$ In normal condition enamel would be more radiograph compared with other body tissue, because enamel consist of $90 \%$ mineral so enamel would be more solid. ${ }^{26}$ On enamel hypoplasia due to the disturbance in matrix deposition either organic or inorganic the density of enamel is lower, as it is reported by Mahoney et al. ${ }^{28}$ that tooth with hypoplasia would get lowering density $10 \%$ or between: $2,30-2,50 \mathrm{gr} / \mathrm{cm}^{3}$. The conclusion is LPS induction during tooth growth and development causing enamel hypoplasia.

\section{REFERENCES}

1. Nancy A. Ten cate's: oral histology (development, structure, and function). $6^{\text {th }}$ ed. St Louis: Mosby Inc; 2003. p. 141-91.

2. McDonald RE, Avery DR, Hartsfield JrJK. Acquired and developmental disturbances of the teeth and associated oral structures. In: McDonald RE, Avery DR, Editor. Dentistry for the child and adolescent. $7^{\text {th }}$ ed. Missouri: Mosby Inc; 2000. p. 115-7.

3. Wikipedia. Lipopolisaccharide. Available from: http://en.wikipedia. org/w/index.php. Accessed February 23, 2006.

4. Sundqvist G. Taxonomy, ecology and pathogenicity of the root canal flora. Oral Surg Oral Med Oral Pathol Oral Radiol Endod 1994; 78:522-30

5. Stashenko P. Interrelationship of dental pulp and apical periodontitis. In: Hargreaves KM, Goodis, Editor. Dental pulp. Chicago: Quintessence Publishing Co Inc; 2002. p. 389-409.

6. Schwartz Z, Goultschin J, Dean DD, Byan BD. Mechanisms of alveolar bone destruction periodontitis. In: Page RC, Kornman KS, Editor. The pathogenesis of perodontitis. Periodontology 2000; 1997. 14:158-72.
7. Schuurs AHB, Moorer WR, Prahl-Andersen B, Van Velzen SKT, Visser JB. Patologi gigi-geligi: kelainan-kelainan jaringan keras gigi. Sutatmi Suryo, editor. Yogyakarta: Gadjah Mada University Press; 1992. p. 61-3.

8. Weerheijm KL, Jalevik B, Alaluusua S, Nonfluoride hypomineralizations in the permanen first molars and their impact on the treatment need. Caries Res 2001; 35:36-40.

9. Li Y, Navia JM, Bian JY. Caries experience in deciduous dentition of rural chinese children 3-5 years old in relation to the presence or absence of enamel hypoplasia. Caries Res 1996; 30(1):8-15.

10. Lo EC, Zheng CG, King NM. Relationship between the presences of demarcated opacities \& hypoplasia in permanent teeth \& caries in their primary predecessors. Caries Res 2003; 37(6): 456-61.

11. Nicolau B, Marcenes W, Bartley M, Sheiham A. A life course approach to assessing causes of dental caries experience: The relationship between biological, behavioral, socio-economic and psychological conditions and caries in adolescents. Caries Res 2003; 37:319-26.

12. Broadbent JM, Thomson WM, Williams SM. Does caries in primary teeth predict enamel defects in permanent teeth? A longitudinal study. J Dent Res 2005; 84(3):260-4.

13. Umezu A, Kaneko N, Toyama Y, Wanatabe Y, Itoh H. Appearance of osteoclast by injections of lipopolysaccharides in rat periodontal tissue. J Periodont Res 1989; 24:378-83.

14. Hargreaves JA, Cleaton-Jones PE, Williams SDL. Hypocalsification and hypoplasia in permanent teeth of children from different ethnic groups in South Africa assessed with a new index. Adv Dent Rest 1989; 3(2):126-31.

15. Jamani KD, Aqrabawi J, Fayyad AM. A radiographic study of the relationship between technical qualiyty of coronoradicular post and periapical status in a jordanian population. J Oral Sci 2005; 47:123-28.

16. Akashi S, Shimazu R, Ogata H, Nagai Y, Takeda K, Kimoto M, Miyake K. Cutting edge: Cell surface expression and lipopolysaccharide signaling via the tool-like receptor 4-MD-2 complex on mouse peritoneal macrophages. J Immunol 2000; 164:3471-5.

17. Ziegle-Heitbrock HWL, Ulevitch RJ. CD14: Cell surface receptor and differentiation marker. Immunol Today. 1993; 14:121-5.

18. Janeway CA, Tarvers P, Walport M, Shlomchik M. Immuno biology. $5^{\text {th }}$ ed. New York: Garland Publishing; 2001. p. 67-8.

19. Yoshimura A, Hara Y, Kaneko T, Kato I. Secretion of IL- $1 \beta$, TNF- $\alpha$, IL-8 and IL-1ra by human polymorphonuclear leukocytes in response to lipopolysaccharides from periodontopathic bacteria. J Periodont Res 1997; 32:279-86.

20. Wikipedia. Tooth enamel. Available from: http:// en.wikipediafoundation.org/w/index.php. Accessed November 28, 2006.

21. Farris, Griffith. The rat in laboratory investigation. New York: Hafner Publishing Co; 1971. p. 124.

22. Heiserman DL. Oral and maxillofacial pathology. Available from: http://www.waybuilder.net/free.ed/qlinks03/contct.asp?usr. Accessed November 28, 2006.

23. Navarro LF, Garcia AA, Marco JM, Llena-Puy MC. A study of the clinical, histopathologic and ultrastructural aspects of enamel agenesis: Report of case. J Dent for Child 1999; 208-12.

24. Gaete M, Lobos N, Torres-Quintana MA. Mouse tooth development time sequence determination for the ICR/Jcl strain. J Oral Sci 2004; 46:135-41.

25. McDonnell ST, Liversidge H, Kinirons M. Temporary arrest of root development in premolar of a child with hypodontia and extensive caries. Int J Paediatr Dent 2004; 14(6):455-60.

26. White SC, Pharooh MJ. Oral radiology: Principles and interpretation. $5^{\text {th }}$ ed. St Louis: Mosby Co; 2004. p. 166-90.

27. Wikipedia. X-ray. Available from: http://en.wikipedia.org/wiki/ Nuclear_Power. Accessed November 28, 2006.

28. Mahoney EK, Ismail FSM, Kilpatrick N, Swain M. Mecahnical properties a cross hypomineralized/hypoplastic enamel of first permanent molar teeth. Eur J Oral Sci 2004; 112:197-502. 